\title{
JPEB
}

Jurnal Penelitian Ekonomi dan Bisnis, 3 (1), 2018, Hal : 48 - 60

http://www.jpeb.dinus.ac.id

\section{PERUSAHAAN KELUARGA DI INDONESIA: MANAGERIAL RENT EXTRACTION AND FIRM PERFORMANCE}

\author{
Melati Oktafiyani $^{*}$ dan Zaky Machmuddah ${ }^{2}$ \\ ${ }^{1,2}$ Program Studi Akuntansi, Fakultas Ekonomi dan Bisnis, Universitas Dian Nuswantoro \\ Jalan Nakula I No. 5-11 Semarang, Indonesia \\ *Corresponding Author: melati.oktafiyani@dsn.dinus.ac.id
}

Diterima: November 2017; Direvisi: Januari 2018; Dipublikasikan: Maret 2018

\begin{abstract}
The revenue authorities world over have continued to show keen interest in firms listed on the stock exchanges due to the complexity of their operations and the tendency for them to come up with complex tax avoidance mechanisms.Tax avoidance may be motivated by a number of factors, but the consequences of such actions can either be positive or negative. This study is therefore motivated by the importance to not only understand the tax avoidance strategy, but to also link tax avoidance as a part of managerial rent extraction to the firm performance.Indonesia is the country of focus because It has concentrated ownership with the ultimate owners of those firms are families.FPEC-Scale with the dimensions of Power are used to obtain a sample of the familyowned firms for all companies listed on the Indonesia stock exchange during the period 2010 - 2014. The results using Ordinary Least Square analysis technique with software of Warppls version 5.0 show that there is a significant negative effect between managerial rent extraction (tax aggressiveness) on firm financial performance.Further, Size of the company has a positively contribute to the company's profitability, Leverage ratio has a negative effect on the firm financial performance.
\end{abstract}

Keywords: Managerial Rent Extraction; Tax Aggressivenes; Firm Performance; Family-Owned Firm; Indonesia

\section{ABSTRAK}

Otoritas pendapatan di seluruh dunia terus menunjukkan minat yang kuat pada perusahaan-perusahaan yang terdaftar di bursa efek karena kompleksitas operasi mereka dan kecenderungan mereka untuk muncul dengan mekanisme penghindaran pajak yang rumit. Penghindaran pajak dapat dimotivasi oleh sejumlah faktor tetapi konsekuensi dari tindakan tersebut dapat menjadi positif atau negatif. Oleh karena itu, penelitian ini didorong oleh pentingnya untuk tidak hanya memahami strategi penghindaran pajak tetapi juga untuk menghubungkan penghindaran pajak sebagai bagian dari managerial rent extraction dengan kinerja keuangan perusahaan. Indonesia adalah negara yang menjadi fokus pada penelitian karena memiliki kepemilikan konsentrasi dari perusahaan-perusahaan tersebut adalah keluarga. FPEC-Scale dengan dimensi Power digunakan untuk memperoleh sampel perusahaan keluarga dari seluruh perusahaan yang terdaftar di Bursa Efek Indonesia selama periode 2010 - 2014. Hasil penelitian dengan teknik Ordinary LeastSquaremenggunakan Warppls versi 5.0 menunjukkan bahwa ada pengaruh negatif yang signifikan antara managerial rent extraction (keagresifan pajak) terhadap kinerja keuangan perusahaan.Selanjutnya, Ukuran perusahaan memiliki kontribusi positif terhadap profitabilitas perusahaan, rasio Leverage memiliki dampak negatif terhadap kinerja keuangan perusahaan.

Kata Kunci: Managerial Rent Extraction; Agresivitas Pajak; Kinerja Keuangan; Perusahaan Keluarga; Indonesia 


\section{PENDAHULUAN}

Penelitian ini merupakan kelanjutan penelitian mengenai pengaruh perencanaan pajak terhadap kinerja perusahaan. Tema penelitian yang membahas pajak merupakan beban bagi perusahaan telah menjadi subjek penelitian yang luas. Dengan demikian, perencanaan pajak untuk mengurangi beban tersebut melalui penghindaran pajak diharapkan memiliki dampak signifikan pada perusahaan. Sementara konsekuensi pajak merupakan faktor pendorong dalam banyak keputusan perusahaan, tindakan manajerial yang dirancang semata-mata untuk meminimalkan kewajiban pajak perusahaan dianggap sebagai fitur aktivitas perusahaan yang semakin penting. Penghindaran pajak dapat dimotivasi oleh sejumlah faktor namun konsekuensi dari tindakan tersebut dapat menjadi positif atau negatif (Desai \& Dharmapala, 2009). Oleh karena itu, penting untuk memeriksa bagaimana kinerja keuangan perusahaan dipengaruhi oleh tingkat penghindaran pajak.

Menurut Dyreng, Hanlon, dan Maydew (2008) dan Hanlon dan Heitzman (2010), penghindaran pajak dapat didefinisikan sebagai aktivitas yang dapat secara eksplisit mengurangi beban pajak perusahaan, tercermin dalam tarif pajak efektifnya, dan mencakup pengurangan pajak yang sepenuhnya legal dan yang menempati daerah abu-abu (Dyreng, et al., 2008).Meskipun ada penghematan pajak yang signifikan yang dihasilkan oleh kegiatan penghindaran pajak (Robinson, dan Schmidt, 2012), terdapat hasil yang variasi mengenai implikasi penghindaran pajak terhadap kinerja keuangan perusahaan (Koester, 2011), terutama karena dampak ini bervariasi dalam penelitian cross-section. Misalnya, kenaikan kinerja perusahaan mungkin diimbangi dengan meningkatnya peluang rent extraction terkait dengan penghindaran pajak.

Otoritas Jasa Keuangan (OJK) akhir-akhir ini menunjukkan banyak minat pada perusahaan yang terdaftar di Bursa Efek Indonesia (BEI) karena kompleksnya operasi mereka dan kecenderungan mereka untuk menghasilkan mekanisme penghindaran pajak yang kompleks. Beberapa perusahaan multinasional besar telah mempertahankan tingkat profitabilitas yang tinggi selama bertahun-tahun karena skema penghindaran pajak yang efisien (PwC, 2013). Oleh karena itu, penting untuk tidak hanya memahami strategi penghindaran pajak tapi juga menghubungkan penghindaran pajak dengan kinerja keuangan perusahaan-perusahaan ini. Perusahaan yang terdaftar di BEI dapat memperoleh manfaat dari strategi penghindaran pajak yang lebih baik. Manfaat ini dapat diterjemahkan ke kinerja keuangan mereka dalam hal peningkatan profitabilitas atau nilai perusahaan (Desai \& Dharmapala, 2009a). Setiap perusahaan selalu berusaha mengelola pajak dengan melakukan perencanaan pajak yang lebih baik dan oleh karena itu penghematan pajak tersebut harus diterjemahkan ke dalam kinerja keuangan yang lebih baik. Konsep ini penting bagi perusahaan yang terdaftar di BEI yang mungkin berusaha memperbaiki savings.

Pada berbagai penelitian yang dilakukan untuk menguji pengaruh penghindaran pajak terhadap kinerja keuangan perusahaan, hasilnya masih bervariasi. Misalnya, Desai \& Dharmapala (2009a) menemukan bahwa penghindaran pajak tidak mempengaruhi nilai perusahaan secara signifikan. Wang (2012) menemukan bahwa penghindaran pajak meningkatkan nilai perusahaan. Selanjutnya, studi oleh Katz et al., (2013) menemukan hubungan negatif antara penghindaran pajak dan profitabilitas masa depan. Selanjutnya tidak ada penelitian yang secara khusus berfokus pada perusahaan keluarga yang terdaftar di BEI.

Tidak seperti perusahaan di A.S dan Inggris yang sahamnya tersebar, satu atau beberapa anggota keluarga memiliki saham merupakan tipe perusahaan di Asia. Perusahaan ini sering berafiliasi dengan kelompok usaha yang juga dikontrol oleh keluarga yang sama, dengan kelompok yang terdiri dari beberapa perusahaan publik dan swasta. Keluarga mencapai kontrol yang efektif dari perusahaan-perusahaan di dalam kelompok dengan menggunakan piramida saham dan kepemilikan silang, yang bisa sangat rumit dalam struktur (Claessens, 
Djankov, \& Lang, 2000). Claessens dkk. (2000) menunjukkan bahwa sebagian besar perusahaan publik di Hongkong, Korea, Philipina, Malaysia, Thailand, Taiwan, Singapura, dan Indonesia memiliki kepemilikan terkonsentrasi, pemilik utama perusahaan tersebut adalah keluarga.

Struktur kepemilikan terkonsentrasi keluarga memiliki karakteristik unik dan berbeda dengan mengacu pada biaya dan manfaat penghindaran pajak dan ini memerlukan penelitian lebih lanjut. Dalam hal penghindaran perpajakan, perusahaan dengan kepemilikan terkonsentrasi keluarga memiliki potensi keuntungan dan biaya yang lebih besar daripada perusahaan kepemilikan non keluarga (Chen et al., 2010). Hal ini karena pemegang saham keluarga memiliki proporsi saham yang lebih besar (pemegang saham mayoritas) dan masa investasi yang lebih panjang, maka keuntungan yang berasal dari penghematan pajak akan lebih besar pula.

Oleh karena itu, penelitian ini bertujuan untuk menginvestigasi pengaruh penghindaran pajak terhadap kinerja keuangan pada perusahaan keluarga yang terdaftar di BEI.

\section{TINJAUAN PUSTAKA}

\section{Teori Keagenan}

Penghindaran pajak menggabungkan lebih banyak dimensi ketegangan agen antara manajer dan investor. Menurut perspektif agensi, masalah yang perlu dipecahkan oleh investor hanyalah ketidakpedulian manajerial. Penghindaran juga mempertimbangkan bentuk lain dari masalah agensi: oportunisme manajerial atau pengalihan sumber daya (Desai dan Dharmapala, 2009b). Desai dan Dharmapala (2006) berpendapat bahwa transaksi penghindaran pajak yang kompleks dapat memberikan pengelolaan alat, masker, dan justifikasi untuk perilaku manajerial oportunistik, seperti manipulasi laba, transaksi pihak terkait, dan aktivitas pengalihan sumber daya lainnya. Dengan kata lain, penghindaran pajak dan pengalihan manajerial bisa saling melengkapi.

Dengan menggunakan analisis kasus, Desai (2005) memberikan bukti tentang bagaimana perilaku oportunistik manajerial dapat difasilitasi oleh penghindaran pajak. Pandangan agensi tentang penghindaran pajak ini menarik perhatian yang meningkat dalam literatur (Hanlon dan Heitzman, 2009). Misalnya, Desai dan Dharmapala (2006) menunjukkan bahwa insentif ekuitas yang diperkuat benar-benar mengurangi penghindaran pajak bagi perusahaan dengan tata kelola yang lemah, sesuai dengan pandangan bahwa penghindaran pajak memfasilitasi pengalihan manajerial. Chen et al., (2010) menemukan bahwa perusahaan keluarga kurang agresif terhadap pajak daripada perusahaan non-keluarga. Hal ini dapatdisimpulkan bahwa pemilik keluarga tampaknya mengabaikan manfaat pajak untuk menghindari biaya non-pajak dari potensi penurunan harga saham yang timbul dari kekhawatiran pemegang saham minoritas tentang tindakan rent extraction keluarga yang ditutupi oleh kegiatan penghindaran pajak.

\section{Kinerja Keuangan Perusahaan}

Kinerja terdiri dari keluaran aktual atau hasil dari sebuah organisasi yang diukur terhadap keluaran atau sasaran dan tujuan yang diinginkan. Menurut Richard et al., (2009) kinerja mencakup tiga bidang spesifik dari hasil perusahaan yaitu kinerja keuangan, kinerja pasar produk dan return saham. Penelitian ini berfokus pada kinerja keuangan yang mengacu pada kinerja berdasarkan indikator keuangan. Pengukuran ini meliputi keuntungan, pengembalian aset, dan imbal hasil ekuitas, dan lainnya.

Dalam literatur penghindaran pajak, kinerja keuangan telah diukur dengan berbagai cara. Misalnya, Wang (2012) mengukur kinerja keuangan perusahaan dengan menggunakan nilai perusahaan yang secara khusus diukur sebagai nilai pasar aset dibagi dengan nilai buku dari total aset. Desai \& Dharmapala (2009b) juga mengukur kinerja keuangan sebagai nilai 
perusahaan menggunakan Tobin's Q. Katz, Khan dan Schmidt (2013) mengukur kinerja keuangan dengan menggunakan profitabilitas. Lebih khusus lagi, mereka mengukur profitabilitas sebagai pengembalian pajak atas equity dan laba atas aset operasi bersih. Penelitian lain menggunakan ukuran seperti biaya ekuitas (Goh, Lee, Lim \& Shevlin, 2013) dan biaya pinjaman bank (Hasan, Hoi, Wu \& Zhang, 2014).

\section{Penghindaran Pajak}

Menurut Hanlon dan Heitzman (2009), penghindaran pajak dapat didefinisikan sebagai pengurangan pajak eksplisit per dolar dari laba akuntansi pra-pajak. Namun, tidak ada definisi penghindaran pajak yang diterima secara universal dalam literatur akuntansi. Berdasarkan definisi yang luas ini, penghindaran pajak merupakan rangkaian strategi perencanaan pajak, yang mencakup kegiatan yang legal secara sempurna (misalnya, investasi obligasi, tunjangan modal, penggunaan pembiayaan hutang) dan transaksi agresif yang masuk ke wilayah abu-abu (misalnya, tax shelter, harga transfer, treaty shopping).

Penghindaran pajak dapat berarti perilaku maksimalisasi nilai manajerial atau potensi konflik agensi yang lebih besar antara manajer dan pemegang saham (Wang, 2012). Selama dua dekade terakhir, beberapa penelitian memberi wawasan yang menarik mengapa beberapa perusahaan menghindari pajak lebih banyak daripada penghindaran yang lain. Studi awal berfokus pada karakteristik perusahaan sebagai proksi peluang, insentif dan sumber daya untuk perencanaan pajak untuk menjelaskan mengapa beberapa perusahaan menghindari pajak lebih banyak daripada yang lain (Rego, 2003). Penelitian terbaru memperluas bidang penelitian ini dengan memeriksa bagaimana konflik keagenan dapat mempengaruhi perilaku penghindaran pajak perusahaan.

Menurut berbagai ilmuwan, dua metode telah digunakan untuk mengukur penghindaran pajak. Metode pertama adalah Book Tax Difference (BTD) yang didefinisikan sebagai perbedaan antara laba keuangan dan penghasilan kena pajak (Desai dan Dharmapala, 2009a). Metode kedua adalah Effective Tax Rate (ETR) yang didefinisikan sebagai rasio beban pajak penghasilan kini dan laba sebelum pajak (Bradshaw, et al., 2013). BTD mengukur penghindaran pajak dan manajemen laba sedangkan metode ETR hanya mengukur penghindaran pajak. Dalam penelitian ini, fokusnya adalah pada ETD sebagai proxy penghindaran pajak.

\section{Ukuran Perusahaan}

Sifat hubungan antara ukuran perusahaan dan kinerja keuangan telah mendapat perhatian yang cukup besar dalam literatur dan telah memicu perdebatan. Beberapa argumen mendukung ukuran perusahaan yang lebih besar dalam mencapai kinerja yang lebih tinggi. Perusahaan besar lebih mungkin mengeksploitasi skala ekonomi dan menikmati kekuatan negosiasi yang lebih tinggi atas klien dan pemasok mereka (Serrasqueiro dan Nunes, 2008). Selain itu, mereka menghadapi lebih sedikit kesulitan dalam mendapatkan akses kredit untuk investasi, memiliki sumber daya manusia manusia yang lebih luas, dan dapat mencapai diversifikasi strategis yang lebih besar (Yang dan Chen, 2009). Di sisi lain, perusahaan kecil menunjukkan karakteristik tertentu yang dapat mengimbangi rintangan yang dikaitkan dengan kekurangan mereka. Mereka memikul lebih sedikit dari masalah agensi dan dicirikan oleh struktur non-hirarkis yang lebih fleksibel, yang mungkin merupakan bentuk organisasi yang tepat dalam mengubah lingkungan bisnis (Yang dan Chen 2009).

Bukti empiris yang ada belum jelas, memberikan dukungan baik terhadap dampak positif dan negatif ukuran perusahaan terhadap kinerja. Yang dan Chen (2009) membandingkan efisiensi teknis UKM dengan perusahaan besar dan tidak meyakinkan tentang hubungan ketika memilih metode estimasi yang berbeda. Dalam sebuah penelitian tentang perusahaan Portugis, Serrasqueiro dan Nunes (2008) menemukan bahwa ukuran berhubungan positif 
dengan kinerja tetapi hanya untuk sampel UKM dan bukan untuk perusahaan besar. Temuan serupa oleh Diaz dan Sanchez (2008) dalam konteks Spanyol menyarankan bahwa UKM lebih efisien daripada perusahaan besar yang memberikan dukungan untuk studi sebelumnya yang mengidentifikasi hubungan terbalik antara ukuran dan kinerja. Studi-studi ini menyiratkan hubungan antara ukuran perusahaan dan kinerja yang mungkin belum tentu linier, seperti yang digambarkan dalam Barrett et al., (2010), Yoon (2004), dan Risseeuw (1997), yang menyimpulkan bahwa pertumbuhan perusahaan di luar tingkat optimal dapat memburuk kinerja.

Hubungan positif antara ukuran perusahaan dan profitabilitas ditemukan oleh Vijayakumar dan Tamizhselvan (2010). Dalam studi mereka, yang didasarkan pada spesifikasi semi-logaritmik sederhana dari model, penulis menggunakan ukuran ukuran yang berbeda (penjualan dan total aset) dan profitabilitas (margin laba dan laba atas total aset) sambil menerapkan model pada sampel 15 perusahaan yang beroperasi di India Selatan. Papadogonas (2007) melakukan analisis pada sampel dari 3035 perusahaan manufaktur Yunani untuk periode 1995-1999. Setelah membagi perusahaan menjadi empat kelas ukuran ia menerapkan analisis regresi yang mengungkapkan bahwa untuk semua kelas ukuran, profitabilitas perusahaan dipengaruhi secara positif oleh ukuran perusahaan. Menggunakan sampel 1020 perusahaan India, Majumdar (1997) menyelidiki dampak bahwa ukuran perusahaan memiliki profitabilitas dan produktivitas perusahaan. Sementara mengendalikan variabel lain yang dapat mempengaruhi kinerja perusahaan, ia menemukan bukti bahwa perusahaan yang lebih besar kurang produktif tetapi lebih menguntungkan.

\section{Struktur Modal}

Studi tentang hubungan antara utang dan kinerja, Jensen (1986) menganggap bahwa utang harus mengharuskan eksekutif untuk mempertahankan hanya proyek yang menguntungkan untuk menghindari kebangkrutan perusahaan. Benar bahwa pembiayaan utang akan mendorong para pemimpin untuk menjadi lebih efisien dan efektif dalam posisi yang diduduki. Namun, sebagian besar penelitian yang telah meneliti hubungan utang, struktur kepemilikan, dan kinerja, didasarkan pada data AS dan Prancis (McGahan dan Porter, 1997).

Selain itu, sehubungan dengan ini, Driffield et al., (2007) mengeksplorasi kemungkinan interaksi antara utang dan kinerja perusahaan menggunakan sistem persamaan simultan. Mereka mengusulkan dua hipotesis alternatif untuk hubungan terbalik ini. Hipotesis pertama berfokus pada perusahaan yang paling sukses. Dalam kasus terakhir, perusahaan yang paling sukses mengurangi tingkat utang mereka untuk melindungi kekayaan pemegang saham dalam risiko kebangkrutan (Saliha,et al., 2011). Dalam konteks yang sama, Abdennadher (2006) menunjukkan pengaruh negatif dan signifikan utang terhadap kinerja dalam konteks Tunisia untuk studi dua puluh perusahaan yang terdaftar selama periode 1996-2000.

\section{Pengaruh Penghindaran Pajak Terhadap Kinerja Keuangan Perusahaan}

Kegiatan penghindaran pajak secara tradisional dipandang sebagai perangkat penghematan atau perencanaan pajak yang mengalihkan sumber daya dari negara kepada pemegang saham dan karenanya harus meningkatkan nilai perusahaan setelah pajak. Namun, sebuah literatur yang muncul dalam ekonomi keuangan menekankan pentingnya implikasi biaya dari penghindaran pajak dan menunjukkan bahwa penghindaran pajak mungkin tidak selalu meningkatkan kekayaan pemegang saham luar. Dari teori keagenan, penghindaran pajak tidak meningkatkan kinerja suatu organisasi karena kegiatan penghindaran pajak dapat mempermudahmanagerial rent extraction dalam berbagai bentuk. Karena biaya gabungan, yang mencakup biaya yang berkaitan langsung dengan kegiatan perencanaan pajak, tambahan biaya kepatuhan, dan biaya non-pajak (misalnya, biaya agensi pada khususnya), mungkin 
lebih besar daripada manfaat pajak kepada pemegang saham, kegiatan penghindaran pajak berpotensi mengurangi nilai perusahaan.

Konsisten dengan teori agensi, Desai dan Dharmapala (2006) menemukan hubungan negatif antara tingkat kompensasi insentif dan tingkat tax sheltering. Asosiasi negatif ini terutama didorong oleh perusahaan-perusahaan yang memiliki tata kelola yang rendah. High power incentives, seperti kompensasi berbasis opsi, kepentingan manajerial yang selaras dengan pemegang saham seharusnya mendorong manajer untuk melakukan penghindaran pajak untuk meningkatkan nilai perusahaan dan mencegah managerial rent extraction. Hubungan negatif antara high-powered incentive dan penghindaran pajak menunjukkan bahwa bagi perusahaan yang memiliki tata kelola yang rendah mengingat sampel yang digunakan adalah perusahaan keluarga, kecenderungan ke arah penghindaran perpajakan lebih banyak diimbangi oleh fakta bahwa pengurangan pengalihan dikaitkan dengan pengurangan tax sheltering.

$\mathrm{H}_{1} \quad$ : Penghindaran pajak berpengaruh negatif terhadap kinerja keuangan perusahaan.

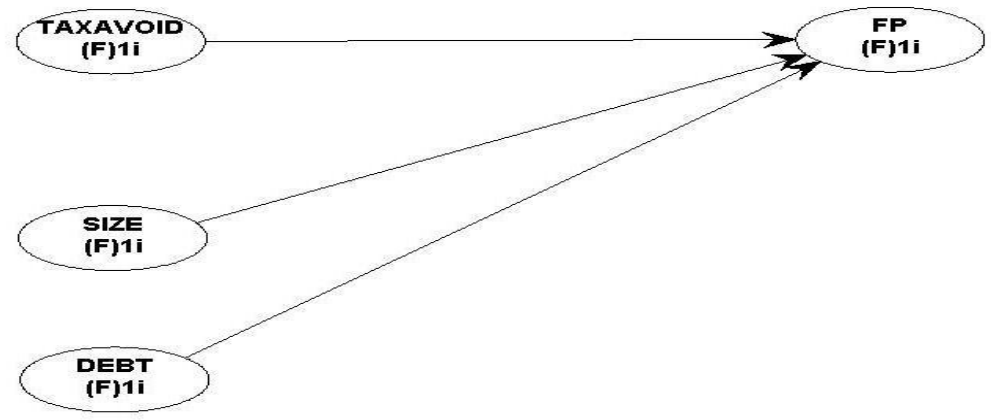

Gambar 1. Kerangka Pemikiran

\section{METODE PENELITIAN}

\section{Populasi dan Sampel Penelitian}

Populasi dalam penelitian ini adalah perusahaan yang terdaftar di Bursa Efek Indonesia selama periode 2010 sampai dengan 2014. Penelitian ini menggunakan metode purposive sampling dalam memperoleh sampel penelitian ke dalam kategori perusahaan dengan kepemilikan terkonsentrasi keluarga. Kategori perusahaan keluarga didefinisikan berdasarkan definisi yang digunakan oleh Giovannini (2010) mengacu pada komponen skala F-PEC (dimensi Power) oleh Astrachan et al. (2002).

Skala yang mendasari dimensi power telah dikelompokkan, untuk membedakan sampel menjadi empat subkelompok. Skala interval F-PEC dari 0 sampai 0,5 menunjukkan bisnis non keluarga; dari 0,5 ke 1 dapat didefinisikan sebagai bisnis keluarga yang lemah, dari 1 sampai 1,5 bisnis keluarga normal, dan untuk nilai di atas 1,5 sebagai bisnis keluarga yang kuat (Giovannini, 2010). Sebuah perusahaan termasuk dalam kelompok sampel penelitian ini jika nilai F-PEC $\geq 0,5$, dengan rumus berikut (Astrachan et al., 2002):

$$
\mathrm{F}-\mathrm{PEC}=\frac{\mathrm{EQ} \mathrm{fam}}{\mathrm{EQ} \mathrm{tot}}+\frac{\mathrm{BoD} \text { fam }}{\text { BoD tot }}+\frac{\text { BoC fam }}{\text { BoC tot }}
$$

Keterangan:

Eqfam : Kepemilikan keluarga

EQtot : Total Kepemilikan

BoDfam : Jumlah anggota keluarga yang menjadi Dewan Direksi 


\author{
BoDtot : Jumlah Dewan Direksi \\ BoCfam : Jumlah anggota keluarga yang menjadi Dewan Komisaris \\ BoCtot : Jumlah Dewan Komisaris
}

Data kepemilikan perusahaan dikumpulkan secara manual dari pernyataan proksi, di mana perusahaan harus mengidentifikasi semua pemegang saham yang memiliki hak kepemilikan atau kontrol atau arahan atas saham yang membawa hak suara (Landry et al., 2013). Mengikuti penelitian sebelumnya (Anderson \& Reeb, 2003; Claessens et al., 2000), perusahaan keluarga merujuk pada pendiri atau anggota keluarga (baik oleh darah maupun pernikahan) adalah manajemen eksekutif, direktur, atau block holders.

Claessens dkk. (2000) menemukan bahwa perusahaan publisitas di Indonesia, kontrol perusahaan ditingkatkan melalui struktur piramida $66,9 \%$ dengan pemilik utama; $1,3 \%$ lintas holding antar perusahaan; 53,4\% pemilik pengendali saja; dan 84,6\% CEO, ketua dewan, atau wakil ketua berasal dari keluarga pengawas. Dengan demikian, penentuan kepemilikan keluarga menelusuri rantai piramidal dan cross-holding secara terpisah dan kemudian menghitung persentase kepemilikan individu (anggota keluarga) dan / atau perusahaan (pemilik akhir adalah satu keluarga/ kelompok keluarga).

Untuk mengetahui apakah anggota keluarga dilibatkan dalam dewan komisaris dan direksi perusahaan, pernyataan proksi digunakan untuk mendapatkan identitas dewan direksi dan anggota eksekutif. Seseorang diidentifikasi sebagai anggota keluarga jika dia memiliki nama belakang yang sama dengan keluarga pemilik atau diberi nama sebagai anggota keluarga dalam pernyataan proksi. Informasi tentang pendiri perusahaan tersebut diperoleh dari pernyataan proksi, situs atau web perusahaan terkait, laporan tahunan, majalah online SWA di rubrik Youngster Inc., majalah online Forbes Indonesia dan beberapa situs bisnis lain yang mempublikasikannya.

Adapun kriteria lain untuk penyeleksian perusahaan sampel, sebagai berikut :

1. Mempublikasikan laporan keuangan diaudit konsisten di Bursa Efek Indonesia dan memiliki data laporan keuangan yang lengkap dari tahun 2010 - 2014. Alasan pemilihan periode dimulai dari 2010 dikarenakan reformasi tarif pajak terbaru berlaku mulai tahun 2010 .

2. Tidak mengalami kerugian selama periode 2010 - 2014 karena perusahaan tersebut akan menghasilkan tarif pajak efektif (ETR) yang terdistorsi (Richardson dan Lanis, 2007).

3. Tidak mempunyai Loss carry forward pada laporan keuangan 2010 - 2014.Adanya Loss carry forward (kerugian fiskal yang masih dapat dikompensasikan di masa datang) akan membuat hasil tarif pajak efektif (ETR) yang didapat sulit untuk diinterpretasi (Adhikari, et al., 2006).

4. Laporan keuangan tidak menggunakan mata uang asing.

\title{
Variabel Penelitian dan Definisi Operasional Variabel Variabel Dependen
}

Alasan profitabilitas digunakan sebagai variabel dependen karena perusahaan, yang lebih menguntungkan cenderung memiliki ETR yang lebih tinggi. Oleh karena itu, perusahaan akan terlihat kurang agresif dalam pajak (Chen, et al., 2010). Profitabilitas diukur dengan ROA (Return On Assets), yang membandingkan jumlah laba sebelum pajak dengan total aset.

\section{Variabel Independen}

Penelitian sebelumnya telah mempertimbangkan tarif pajak efektif atau Effective Tax Rate(ETR) sebagai proksi untuk beban pajak perusahaan (Gupta \& Newberry, 1997; Porcano, 1986; Salihu, Obid, \& Annuar, 2013; Wu, et al., 2012). Ini sekaligus merupakan indeks penting yang digunakan untuk mengukur efektivitas penghindaran pajak. Studi ini 
mengadopsi tarif pajak efektif (ETR) untuk mewakili penghindaran pajak (strategi berisiko dan tidak berisiko) (Badertscher, et al., 2013). ETR didefinisikan berdasarkan GAAP sebagai beban pajak penghasilan kini(current income tax expense)dibagi dengan laba sebelum pajak (pretax income).

\section{Variabel Kontrol \\ Ukuran Perusahaan}

Richardson dan Lanis (2007) menyatakan bahwa perusahaan besar akan cenderung memiliki ETR yang lebih rendah, ini karena perusahaan yang lebih besar mengelola sumber daya mereka untuk membuat perencanaan pajak yang lebih baik juga (teori kekuatan politik). Namun, tidak semua perusahaan dapat selalu menggunakan kekuatan mereka untuk melakukan perencanaan pajak karena resistensi kemungkinan untuk menjadi perhatian atau target kebijakan regulasi - political cost theory (Watts dan Zimmerman, 1986; Richardson dan Lanis, 2007). Oleh karena itu, ukuran perusahaan (Ukuran) digunakan sebagai variabel kontrol. Selain itu, ukuran perusahaan diukur dengan log Total Aset.

\section{Struktur Modal}

Pembayaran bunga atas pembiayaan perusahaan melalui utang dapat membuat ETR perusahaan lebih rendah. Hal ini sesuai dengan Undang-Undang Pajak Penghasilan No 36 tahun 2008 yang menyatakan bahwa bunga biaya pinjaman adalah biaya yang dapat dikreditkan atau sebagai pengurang dari penghasilan kena pajak. Penelitian ini menggunakan rumus berikut untuk mengukur ukuran Struktur Modal:

Leverage $($ DEBT $)=($ Hutang jangka panjang $) /($ Total Aset $)$

\section{Teknik Analisis}

Pertama, analisis deskriptif digunakan untuk menggambarkan data dalam hal skor ratarata dan standar deviasi di antara statistik deskriptif lainnya. Kedua, untuk menguji tingkat penghindaran pajak di antara perusahaan, nilai rata-rata dan median digunakan untuk menginterpretasikan hasil. Untuk menguji pengaruh penghindaran pajak terhadap kinerja, analisis regresi dilakukan. Analisis dilakukan menggunakan teknik Ordinary Least Square (OLS) dengan bantuan perangkat lunak analisis WarpPLS versi 5.0.Model yang akan dikembangkan dalam penelitian ini adalah:

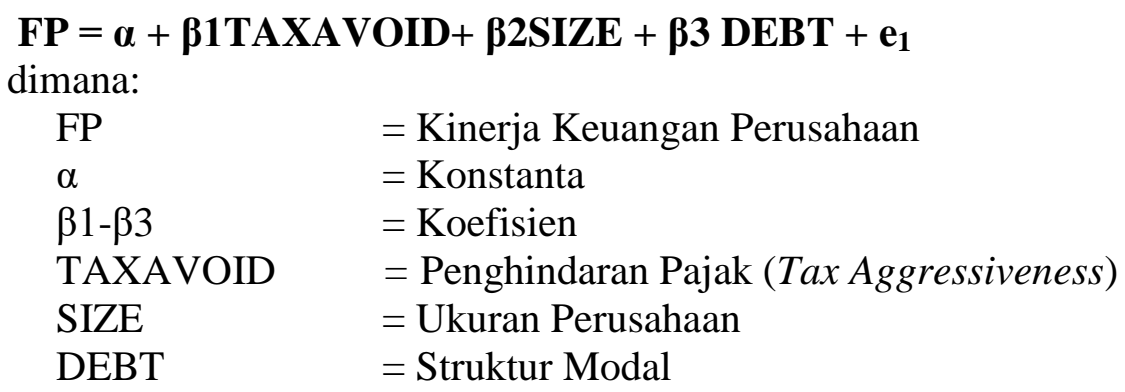

\section{HASIL DAN PEMBAHASAN}

Set data yang digunakan dalam analisis utama adalah data panel sejumlah 215 data observasi dari 43 perusahaan milik keluarga untuk periode 2010 - 2014 dan merupakan perusahaan - perusahaan non keuangan, konsisten dengan penelitian sebelumnya.Proses pemilihan sampel ditunjukkan tabel berikut. 
Tabel 1. Pemilihan Sampel

\begin{tabular}{lcc}
\hline Sampel & Perusahaan & $\begin{array}{c}\text { Data } \\
\text { Observasi }\end{array}$ \\
\hline $\begin{array}{l}\text { Perusahaan non keuangan yang terdaftar di BEI } \\
(2010-2014)\end{array}$ & 288 & 1440 \\
$\begin{array}{l}\text { Pengurangan sampel berdasarkan kriteria } \\
\text { Perusahaan dengan permodalan asing (Non- } \\
\text { PMDN) }\end{array}$ & 72 & \\
Perusahaan yang memperoleh skala FPEC <0,5 & 145 & \\
$\begin{array}{l}\text { Penyajian laporan keuangan tidak dalam rupiah } \\
\text { Perusahaan menderita kerugian }\end{array}$ & $\mathbf{7}$ & \\
$\begin{array}{l}\text { Perusahaan melaporkan kerugian fiskal yang } \\
\text { masih dapat dikompensasikan di masadating }\end{array}$ & 17 & \\
$\begin{array}{l}\text { Perusahaan yang tidak mempublikasi laporan } \\
\text { keuangan dan laporan tahunan }\end{array}$ & 3 & $\mathbf{2 1 5}$ \\
\hline \multicolumn{1}{c}{ Sampel akhir } & $(245)$ & $(1225)$ \\
\hline
\end{tabular}

\section{Statistik Deskriptif}

Tabel 2. Statistik Deskriptif Sampel Perusahaan

\begin{tabular}{lcccc}
\hline & FP & TAXAGG & SIZE & DEBT \\
\hline Mean & 0.1014 & 0.0297 & 6.2896 & 0.1908 \\
Median & 0.0782 & 0.0182 & 6.2826 & 0.1590 \\
Maximum & 0.4324 & 0.4558 & 7.7652 & 0.6603 \\
Minimum & 0.0001 & 0.0001 & 4.9532 & 0.0013 \\
Std. Dev. & 0.0779 & 0.0446 & 0.6399 & 0.1473 \\
Skewness & 1.5714 & 5.9406 & 0.1079 & 0.7524 \\
Kurtosis & 6.0276 & 50.0353 & 2.1445 & 2.8744 \\
Sum & & & & \\
Sum Sq. Dev. & 1.21 .8001 & 6.3865 & 1352.272 & 41.0307 \\
& & 0.4253 & 87.6466 & 4.6436 \\
Observations & 215 & 215 & 215 & 215 \\
\hline
\end{tabular}

Tabel 2 menunjukkan bahwa kinerja keuangan memiliki rata-rata 0,1014dan standar deviasi 0,0779 . Itu adalah kinerja keuangan dari 43 perusahaan yang terdaftar selama periode studi tercatat bahwa rata-rata ROA sebesar $10,14 \%$. Namun, kisaran nilai tertinggi mencapai $43,42 \%$ dan terendah sebesar $0,01 \%$. Penghindaran pajak rata-rata perusahaan sambel sebesar $2,97 \%$ dengan penghindaran pajak maksimum mencapai $45,58 \%$ untuk 43 perusahaan yang terdaftar selama periode penelitian.

Nilai rata-rata struktur modal yang diukur dengan leverage adalah 0,1908 yang menyiratkan 19,08\% dari total kewajiban jangka panjang dibagi dengan total aset perusahaan selama periode penelitian.

\section{Model Regresi}

Metode regresi yang digunakan untuk penelitian ini adalah metode ordinary least square. Ini digunakan untuk menentukan garis yang paling cocok untuk model melalui 
meminimalkan jumlah kuadrat jarak dari titik ke garis yang paling sesuai. Melalui metode ini, analisis diasumsikan linearitas antara variabel dependen dan variabel independen. Hasil regresi diambil untuk ringkasan model, analisis varians dan koefisien regresi.

\section{Pengujian Model (Goodness of Fit)}

Hasil estimasi model menunjukkan bahwa kriteria goodness of fit telah terpenuhi, nilai Average R-squared (ARS) dan Average Path Coefficient (APC) secara statistik signifikan, dan nilai Average Variance Inflation Factor (AVIF) lebih kecil dari 5 (Kock, 2011). Hasil ini disajikan dalam tabel berikut.

Tabel 3. Hasil Pegujian Model (Goodness of Fit)

\begin{tabular}{lccc}
\hline \multicolumn{1}{c}{ Jalur } & \multicolumn{2}{c}{ Hasil Pengaruh } & \multirow{2}{*}{ Keterangan } \\
\cline { 2 - 3 } & Koefisien & Prob. & \\
\hline TAXAVOID $\rightarrow$ FP & $-0,174$ & $0,004^{* * *}$ & H1is accepted \\
SIZE $\rightarrow$ FP & 0,206 & $<0,001^{* * *}$ & \\
DEBT $\rightarrow$ FP & $-0,354$ & $<0,001^{* * *}$ & \\
& & & \\
\hline Model Fit Indicators & & & \\
\hline $\begin{array}{l}\text { Average Path Coefficient } \\
\text { (APC) }\end{array}$ & 0,243 & $<0,001^{* * *}$ & \\
$\begin{array}{l}\text { Average R-square (ARS) } \\
\text { Average Variance Inflation } \\
\text { Factor (AVIF) }\end{array}$ & 0,245 & $<0,001^{* * *}$ & \\
\hline
\end{tabular}

Catatan: *,**, dan $* * *$ menunjukkan signifikansi (satu-sisi) pada 0,$10 ; 0,05$; dan 0,01 tingkat, masing-masing.

\section{Pengujian Hipotesis}

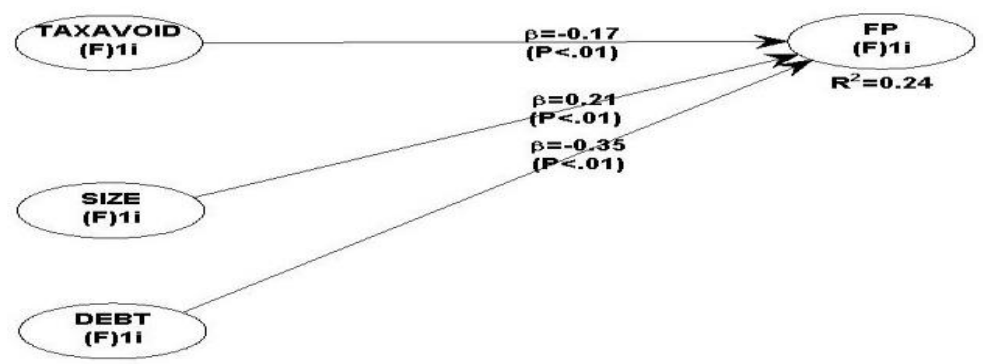

Gambar 2. Hasil Output dengan WarpPls 5.0

Hasil pengujian menunjukkan nilai koefisien $(-0,174)$ dengan tingkat signifikansi sebesar 0,004 artinya bahwa penghindaran pajak berpengaruh negatif terhadap kinerja keuangan perusahaan sehingga $\mathrm{H} 1$ diterima.

Peningkatan unit dalam ukuran perusahaan akan menyebabkan peningkatan 0,206 unit $(20,6 \%)$ kinerja keuangan perusahaan. Peningkatan unit dalam rasio leverage akan mengarah ke 0,354 unit $(35,4 \%)$ penurunan kinerja keuangan perusahaan yang termasuk dalam perusahaan keluarga.

\section{SIMPULAN}

Reformasi perpajakan telah menjadi pilar utama reformasi ekonomi secara keseluruhan yang banyak diupayakan oleh pemerintah untuk menyeimbangkan anggaran pemerintah. Dengan menggunakan data pada perusahaan-perusahaan yang terdaftar di Bursa 
Efek Indonesia, Penelitian ini menganalisis dampak penghindaran pajak perusahaan terhadap kinerja perusahaan keluarga di Indonesia. Hal ini diperlukan karena penghindaran pajak, jika tidak ditindak dengan hati-hati, akan mempermasalahkan pendapatan pemerintah yang akan diperlukan untuk membiayai pengeluaran pemerintah. Hasilpenelitian ini menunjukkan bahwa perilaku pengindaran pajak perusahaan keluarga di Indonesia mempunyai pengaruh negatif terhadap kinerja keuangan mereka.

Penghindaran pajak telah didefinisikan sebagai pengurangan kewajiban pajak eksplisit perusahaan (Hanlon \& Heitzman, 2010). Oleh karena itu, penghindaran pajak terdiri dari strategi perencanaan pajak dengan kegiatan legal yang sempurna pada penghindaran pajak yang ekstrim dan ilegal pada yang lain (Hanlon \& Heitzman, 2010).Penghindaran pajak perusahaan secara tradisional dipandang sebagai alat pengurang pajak yang mengalihkan bunga dari pemerintah kepada pemegang saham untuk memaksimalkan nilai pemegang saham, meskipun perluasan badan kerja pada teori agensi menekankan bahwa penghindaran pajak terkait erat dengan tata kelola perusahaan karena implikasi biaya agensi.

Dalam prakteknya, kompleksitas dan ambiguitas penghindaran pajak dapat melindungi manajer yang terlibat dalam berbagai bentuk managerial rent extraction seperti manipulasi laba dan transaksi orang dalam yang akan mengurangi arus kas setelah pajak (Desai \& Dharmapala, 2009; Desai, Dyck, \& Zingales, 2007). Kasus Enron adalah contoh yang mencolok. Pada 1990-an, Enron memanfaatkan transaksi pembiayaan terstruktur untuk menghindari pajak, yang mengarah ke penuntutan pemerintah dan keruntuhannya. Di luar itu, perusahaan juga harus menanggung biaya penghindaran pajak gabungan, yang termasuk perencanaan pajak langsung, kepatuhan dan biaya non-pajak. Lee, Dobiyanski, dan Minton (2015) menyatakan bahwa jika pemegang saham tidak dapat sepenuhnya memahami kalkulasi biaya-manfaat, kegiatan penghindaran pajak benar-benar dapat mengurangi kinerja keuangan perusahaan.Oleh karena itu, penghindaran pajak perusahaan mungkin tidak selalu meningkatkan nilai perusahaan.

\section{DAFTAR PUSTAKA}

Adhikari, A., Derashid, C., \& Zhang, H. 2006. Public policy, political connections, and effective tax rates: Longitudinal evidence from Malaysia. Journal of Accounting and Public Policy. 25(5): 574-595.

Anderson, R. C., \& Reeb, D. M. 2003. Founding-family ownership and firm performance: evidence from the S\&P 500. The journal of finance. 58(3): 1301-1328.

Astrachan, J. H., Klein, S. B., \& Smyrnios, K. X. (2002). The F-PEC scale of family influence: A proposal for solving the family business definition problem1. Family Business Review. 15(1): 45-58.

Badertscher, B.A., Katz, S.P., \& Rego, S.O. 2013. The separation of ownership and control and corporate tax avoidance. Journal of Accounting and Economics. 56(2): 228-250.

Barrett, C.B., Bellemare, M.F., and Hou, J.Y. 2010. Reconsidering Conventional Explanations of the Inverse Productivity-Size Relationship. World Development. 38 (1): 88-97.

Bradshaw, M. Liao, G. and Ma, M. 2013. Ownership Structure and Tax Avoidance: Evidence from Agency Costs of State Ownership in China. Available at: http://ssrn.com/abstract=2239837.

Chen, S., Chen, X., Cheng, Q., and Shevlin, T.J. 2010. Are Family Firms More Tax Aggressive Than Non-family Firms? Journal of Financial Economics. 95: 41-61.

Claessens, S., Djankov, S., \& Lang, L. H. 2000. The separation of ownership and control in East Asian corporations. Journal of financial Economics. 58(1): 81-112. 
Diaz, M.A. and Sanchez, R. 2008. Firm Size and Productivity in Spain: a Stochastic Frontier Analysis. Small Business Economics. 30 (3): 315-323.

Desai, M.A., \& Dharmapala, D. 2006. Corporate Tax avoidance and high-powered incentives. Journal of Financial Economics. 79(1): 145-179.

Desai, M.A., Dyck, A., \& Zingales, L. 2007. Theft and taxes. Journal of Financial Economics, 84(3), 591-623.

Desai, M.A., and Dharmapala, D. 2009. Corporate Tax Avoidance and Firm Value. The Review of Economics and Statistics. 91: 537-546.

Desai, M.A., \&Dharmapala, D. 2009. Earnings management, corporate tax shelters, and book-tax alignment.National Tax Journal. 169-186.

Driffield, N., Mahambare, V., and Pal, S. 2007. How Does Ownership Structure Affect Capital Structure and Firm Performance? Recent Evidence from East Asia. Economics of Transition. 15 (3): 535-573.

Dyreng, S.D., Hanlon, M., \& Maydew, E.L. 2008. Long-run corporate tax avoidance. Accounting Review. 83(1): 61-82.

Goh, B.W., Lee, J., Lim, C.Y., and Shevlin, T. 2013.The Effect of Corporate Tax Avoidance on the Cost of Equity. Available at: http://ssrn.com/abstract=2237742.

Giovannini, R. Corporate governance, family ownership and performance. 2010. J. Manag. Gov. 14: 145-166.

Gupta, S., \& Newberry, K. 1997. Determinants of the variability in corporate effective tax rates: Evidence from longitudinal data. Journal of Accounting and Public Policy. 16(1): 1-34.

Hanlon, M., \& Heitzman, S. 2010. A review of tax research. Journal of Accounting and Economics. 50(2): 127-178.

Jensen M. 1986. Agency Costs of Free Cash Flow, Corporate Finance and Takeovers. American Economic Review. 76(2): 323-329.

Hasan, I., Hoi, C.K., Wu, Q, and Zhang, H. 2014. Beauty is in the Eye of the Beholder: The Effect of Corporate Tax Avoidance on the Cost of Bank Loans. Bank of Finland Research Discussion Papers 3, Bank of Finland.

Katz, S., Khan, U. and Schmidt, A.P. 2013.Tax Avoidance and Future Profitability. Available at: http://ssrn.com/abstract=2227149.

Koester, A. 2011. Investor Valuation of Tax Avoidance through Uncertain Tax Positions.Working Paper, Georgetown University.

Landry, S., Deslandes, M., \& Fortin, A. 2013. Tax aggressiveness, corporate social responsibility, and ownership structure.

latLee, B.B., Dobiyanski, A., \& Minton, S. 2015. Theories and empirical proxies for corporate tax avoidance. The Journal of Applied Business and Economics. 17(3): 21-34.

Majmumdar SK. 1997.. The Impact of Size and Age in Firm-Level Performance: Some Evidence from India. Review of Industrial Organization. 12: 231-241.

McGahan, A.M. and Porter, M.E. 1997. The Emergence and Sustainability of Abnormal Profits. Working Paper, Harvard Business School.

Papadogonas, T.A. 2007. The Financial Performance of Large and Small Firms: Evidence from Greece. International Journal of Financial Service Management. 2(1/2): 1420.

Porcano, T. 1986. Corporate tax rates: Progressive, proportional, or regressive. Journal of the American Taxation Association. 8(2): 17-31.

PwC. 2013.Growing Scrutiny of international transactions. Journal of International Transfer Pricing. 33:1-6.

Rego, S. (2003). Tax-avoidance Activities of U.S. Multinational Corporations. Contemporary Accounting Research. 20 (4): 805-833. 
Richard, P. J., Devinney, Y., and Johnson, G. 2009. Measuring Organizational Performance: Towards Methodological Best Practice. Journal of Management. 35(1): 113-133.

Richardson, G., Lanis, R. 2007. Determinants of variability in corporate effective tax rates and tax reform: Evidence from Australia. Journal of Accounting and Public Policy. 26: 689- 704.

Risseeuw, P. 1997. Estimating the Determinants of Financial Performance of Very Small Service Firms in United States Association for Small Business and Entrepreneurship. San Francisco, California.

Robinson, L., and Schmidt, A. 2012. Firm and Investor Responses to Uncertain Tax Benefit Disclosure Requirements.Working Paper, Dartmouth University and North Carolina State University.

Saliha, T. and Abdessatar, A. 2011. The Determinants of Financial Performance: an Empirical Test Using the Simultaneous Equations Method. Economics and Finance Review. 1(10): $01-19$.

Salihu, I.A., Obid, S.N.S., \& Annuar, H.A. 2013. Measures of corporate tax avoidance: Empirical evidence from an emerging economy. International Journal of Business and Society. 14(3): 412-427.

Serrasqueiro, Z.S. and Nunes, P.M. 2008. Performance and Size: Empirical Evidence from Portuguese SMEs. Small Business Economics. 31 (2): 195-217. . Undang-undang Pajak Penghasilan Nomor 36 Tahun 2008. http://ketentuan.pajak.go.id/index.php?r=aturan/rinci\&idcrypt=oJeko6A\%3D

Vijayakumar A, and Tamizhselvan, P. 2010. Corporate Size and Profitability: An Empirical Analysis. Journal for Bloomers of Research. 3(1): 44-53.

Wang, X. 2012.Tax Avoidance, Corporate Transparency, and Firm Value.Working Paper, University of Texas Austin.

Watts, R. and Zimmerman, J. 1978. Towards a Positive Theory of the Determination of Accounting Standards. The Accounting Review. 53 (1): 112-134.

Watts, R., Zimmerman, J. 1986. Towards a Positive Theory of Accounting. New Jersey: Prentice-Hal

Wu, L., Wang, Y., Luo, W., \& Gillis, P. 2012. State ownership, tax status and size effect of effective tax rate in China. Accounting and Business Research. 42(2): 97-114.

Yang, C.H. and Chen, K.H. 2009. Are Small Firms Less Efficient? Small Business Economics. 32 (4): 375-395.

Yoon, S. 2004.A Note on the Market Structure and Performance in Korean Manufacturing Industries. Journal of Policy Modelling. 26 (6): 733-746. 